\title{
The Effect of Vitamin D Metabolic Status and Endometrial Immune Patterns on the Outcomes of ART Programs
}

\author{
Elena G. Chukhnina ${ }^{1}$, PGS; Evgeny L. Kazachkov ${ }^{1}, \mathrm{PhD}, \mathrm{ScD}$; Ekaterina E. Voropaeva ${ }^{1}$, \\ $\mathrm{PhD}$, ScD; Ella A. Kazachkova ${ }^{1}, \mathrm{PhD}$, ScD; Miroslava L. Polina ${ }^{2}, \mathrm{PhD}$; \\ Natalya I. Douglas ${ }^{3}, \mathrm{PhD}, \mathrm{ScD}$ \\ ${ }^{1}$ South Ural State Medical University, Chelyabinsk, Russia \\ ${ }^{2}$ Women's Health Medical Center, Moscow, Russia \\ ${ }^{3}$ Medical Institute of North-Eastern Federal University named after M.K. Ammosov, Yakutsk, Russia
}

\begin{abstract}
The objective of this study was to assess the possibility of predicting the outcomes of in vitro fertilization (IVF) and IVF/ ICSI (intracytoplasmic injection [transfer] of sperm into eggs), protocols based on the serum vitamin D content and endometrial expression of vitamin D receptor (VDR), CD4+T cells, and CD8+T cells.

Methods and Results: The results of IVF and IVF/ICSI programs were analyzed in 147 patients of older reproductive age (36-44 years of age) with tubal-peritoneal factor of infertility. Depending on the outcomes of ART programs, 2 groups were formed. Group 1 included 37 women with the onset of pregnancy; Group 2 included 110 women with negative outcomes of ART programs.

The level of 25(OH)D in the blood serum and follicular fluid (FF) was assessed. The sampling of the material (blood and FF) was carried out on the day of ovarian puncture, the 25(OH)D content - at least three days after the last administration of the drug. Anti-Müllerian hormone (AMH) was determined using AMH reagent (AMH Gen II ELISA) and the Beckman Coulter Access ${ }^{\circledR} 2$ Immunoassay System (Beckman Coulter, Inc. USA). Morphological examination of the endometrium was performed after biopsy sampling by pipelle biopsy on Day 7 after confirmed ovulation in the cycle preceding ART. The endometrial expression of VDR, CD4+Tcells, and CD8+Tcells was evaluated in 68 women of the sample: 18 - with pregnancy, 50 - with negative outcomes in ART programs.

Vitamin D deficiency $(<20 \mathrm{ng} / \mathrm{ml})$ in peripheral blood was detected only in Group 2. Low levels of vitamin D $(20-<30 \mathrm{ng} / \mathrm{ml})$ in women of this group were four times more frequent $(\mathrm{p}=0.008)$ than in Group 1 . Women with the onset of clinical pregnancy were more often distinguished by the optimal content of vitamin D in biological fluids - almost twice as much as those with ineffective attempts to treat infertility $(P=0.009$ for peripheral blood). The mean value of the $25(\mathrm{OH}) \mathrm{D}$ content in the blood serum in both groups did not differ; in FF it was significantly higher in Group 1 than in Group $2(P=0.003)$. A strong correlation was revealed between the content of $25(\mathrm{OH}) \mathrm{D}$ in the blood serum and $\mathrm{FF}$ ( $\mathrm{r}=0.67, P=0.003$ in both groups), a weak correlation - in cases where it was impossible to sample oocytes and/or embryos $(\mathrm{r}=0.48, P=0.06)$. The VDR expression in stromal epithelium was higher in Group 2 than in Group $1(P=0,016)$. It is calculated that a $1 \%$ decrease in VDR expression in the stroma increases the chance of a favorable outcome by 1.35 times. The density of labels of CD4+T cells and CD8+T cells in the endometrial stroma did not differ significantly between groups. The expression of CD4+T cells and CD8+T cells in endometrial samples taken from the same infertile women in different phases of the menstrual cycle showed no statistically significant differences.

Conclusion: Morphofunctional peculiarities of the endometrium of infertile women are the basis for predicting the outcomes of ART programs and preparing for pregnancy. (International Journal of Biomedicine. 2021;11(2):188-196.)
\end{abstract}

Key Words: assisted reproductive technology $\bullet$ follicular fluid $\bullet 25(\mathrm{OH}) \mathrm{D} \bullet$ vitamin D receptor

For citation: Chukhnina EG, Kazachkov EL, Voropaeva EE, Kazachkova EA, Polina ML, Douglas NI. The Effect of Vitamin D Metabolic Status and Endometrial Immune Patterns on the Outcomes of ART Programs. International Journal of Biomedicine. 2021;11(2):188-196. doi:10.21103/Article11(2)_OA11

\section{Abbreviations}

ART, assisted reproductive technology; AMH, anti-Müllerian hormone; FF, follicular fluid; FSH, follicle-stimulating hormone; IVF, in vitro fertilization; ICSI, intracytoplasmic sperm injection; OR, ovarian reserve; VDR, vitamin D receptor. 


\section{Introduction}

Implantation failures are one of the reasons for the ineffectiveness of ART programs, often due to abnormal molecular transformation of the «implantation window» period. ${ }^{(1)}$ Disturbances in the embryo integration process aroused interest in analyzing the expression of regulatory and structural proteins of the endometrium, prostaglandins, cytokines, growth factors, surface epithelial cells with the presence of mature pinopodia, and steroid hormone receptors during the "implantation window." (2-4)

The involvement of some cell adhesion proteins in the stromal decidualization, necessary for embryo implantation, indicates the prospects of analyzing their expression. ${ }^{(5,6)}$

Interest in the role of vitamin D in the functional activity of the endometrium is due to its numerous biological functions - regulation of not only calcium-phosphorus metabolism, but also anti-inflammatory and antiproliferative effects. ${ }^{(7)}$ The developed VDR network in the organs of the reproductive system (ovaries, endometrium, fallopian tube epithelium, placenta, decidual cells, hypothalamus and pituitary gland) explains its prognostic potential in the study of infertility causes. ${ }^{(8,9)}$ The role of vitamin D as a cofactor for changes in endometrial activity (proliferation processes, secretory transformations, desquamation) has been studied mainly in experiments on biological models.

The effect of vitamin D on the endometrium is carried out by various mechanisms - the formation of a ligand-dependent transcription factor in the cell nucleus for the regulation of target genes and non-genomic effects due to the connection with cytosolic and membrane receptors..$^{(10,11)}$

The steroid activity of vitamin D determines the ability to modulate genes encoding proteins involved in the processes of proliferation, differentiation, and apoptosis. An indicator of the body's vitamin D saturation is the circulation of the intermediate active metabolite $25(\mathrm{OH}) \mathrm{D}$ in the blood, but the effectiveness of regulation of the signaling pathways is caused by the interaction of vitamin D with VDR in the endometrium. ${ }^{(10,12,13)}$

VDR expression under the influence of genetic and epigenetic factors leads to change in the metabolism of vitamin $\mathrm{D}$ in the endometrium. ${ }^{(14)}$ The effect of the active 1,25-dihydroxyvitamin D3 [1,25(OH)2D3] form on the expression of immune and hormone-mediated reactions determines the role of $1,25(\mathrm{OH}) 2 \mathrm{D} 3$ deficiency in the genesis of gynecological diseases. ${ }^{(7)}$

Unsatisfactory outcomes of ART programs among women with vitamin D deficiency were noted by Pacis et al. ${ }^{(15)}$ In ART programs, there have been reports of the correlation of serum vitamin D with the quality of oocytes, ${ }^{(16)} \mathrm{AMH}$, the number of antral follicles, ${ }^{(17,18)}$ the number and quality of embryos, ${ }^{(19)}$ and the frequency of clinical pregnancy ${ }^{(20,21)}$ and live birth. ${ }^{(19,22,23)}$

The relationship of $25(\mathrm{OH}) \mathrm{D}$ content in the blood serum and FF with the outcomes of ART programs, in particular the frequency of pregnancy, is denied by many researchers. ${ }^{(23-25)}$ Similar observations were made in women with infertility, polycystic ovary syndrome, and normal OR. ${ }^{(26)}$ The lack of correlation of vitamin D levels with ovarian response to stimulation and embryo quality in IVF/ICSI cycles, especially when using donor oocytes, suggests the influence of vitamin D on the morphofunctional state of the endometrium. ${ }^{(20,21)}$

The negative results may be explained by the need to analyze the mechanisms of interaction between the active form of vitamin D and the functional VDR activity in the endometrium of women with infertility. Effective interaction between the endometrium and the blastocyst during the implantation window suggests maternal tolerance, determined by the consistency of local immune patterns..$^{(14)}$

An imbalance in the Th1/Th2 subset of CD4+Tcells with a predominance of the Th1 subset producing proinflammatory cytokines is indicated as a possible cause of miscarriage. (27) Vitamin D regulation of systemic and local immune responses is associated with the ability of Th2 cells to induce cytokines IL-4, IL-5, IL-6, IL-9, IL-10, and IL-13 and to reduce the proliferation of Th1 cells. ${ }^{(6,28)}$

The search for factors that improve reproductive outcomes, especially in IVF-ICSI cycles, has led to an interest in assessing the content of vitamin D in blood serum and the expression of its receptors and individual immune clusters in the endometrium.

The objective of this study was to assess the possibility of predicting the outcomes of in vitro fertilization (IVF) and IVF/ ICSI (intracytoplasmic injection [transfer] of sperm into eggs), protocols based on the serum vitamin $\mathrm{D}$ content and endometrial expression of VDR, CD4+T cells, and CD8+T cells.

\section{Materials and Methods}

The results of IVF and IVF/ICSI programs were analyzed in 147 patients of older reproductive age (36-44 years of age) with tubal-peritoneal factor of infertility in the Center of Obstetrics and Gynecology \#1 (Chelyabinsk) and the Medical Center for Women's Health (Moscow), using their own oocytes in "fresh" cycles and cryoprotocols (in delayed embryo transfer, for example, due to preimplantation genetic diagnosis).

Inclusion criteria for the study were tubal factor of infertility, normal or reduced ovarian reserve with a preserved regular ovulatory menstrual cycle, use of the patient's own oocytes, normozoospermia or mild pathozoospermia.

Exclusion criteria were oocyte donation, uterine fibroids more than $3 \mathrm{~cm}$, polycystic ovary syndrome, HIV infection, hepatitis $\mathrm{B}$ and $\mathrm{C}$.

Depending on the outcomes of ART programs, 2 groups were formed. Group 1 included 37 women with the onset of pregnancy; Group 2 included 110 women with negative outcomes of ART programs. Embryos were obtained in 115 women, and a negative result (absence of oocytes and/or embryos) occurred in 32 women.

We performed 53 programs of IVF and 94 programs of IVF/ICSI. Pregnancy rate was $25.7 \%$ per cycle, $32.2 \%$ - for the transfer. One hundred and eighteen women used a stimulation protocol with antagonists of gonadotropinreleasing hormones $(\mathrm{GnRH}), 8$ - a long classic protocol, 14 - a modified long protocol with half doses of GnRH agonists, 7 - a short protocol with agonists. The average duration of stimulation was $10.4 \pm 1.7$ days. 
Obtaining oocytes, fertilization, cultivation and transfer of embryos (no more than two), support of the luteal phase with progesterone preparations in the post-transfer period was carried out according to the existing recommendations. Only clinically confirmed pregnancy was taken into account on sonographic imaging of the ovum.

In this sample $(\mathrm{n}=147)$, the level of $25(\mathrm{OH}) \mathrm{D}$ in the blood serum and FF was assessed. The sampling of the material (blood and FF) was carried out on the day of ovarian puncture, the $25(\mathrm{OH}) \mathrm{D}$ content - at least three days after the last administration of the drug.

AMH was determined using AMH reagent (AMH Gen II ELISA) and the Beckman Coulter Access ${ }^{\circledR} 2$ Immunoassay System (Beckman Coulter, Inc. USA). The studies were carried out on the basis of the central research laboratory of the South Ural State Medical University, the laboratory "Gemotest" (Moscow) using the ELISA system (Personal $\mathrm{Lab}$ ) and the 25(OH) Vitamin D ELISA kit (Euroimmun AG, Germany).

Ultrasound examination was performed to assess induced folliculogenesis and pregnancy (Voluson E6 system, GE Healthcare, USA).

Morphological examination of the endometrium was performed after biopsy sampling by pipelle biopsy on Day 7 after confirmed ovulation in the cycle preceding ART. Of these, 20 women who underwent hysteroscopy, had additional endometrial sampling during the proliferative phase of the menstrual cycle. The endometrial samples were processed according to the standard technique to obtain paraffin sections with a thickness of 3-5 microns. Morphological studies were performed at the Department of Pathological Anatomy and Forensic Medicine of the South Ural State Medical University (SUSMU). For histological examination, the standard method of fixation in $10 \%$ neutral formalin and embedding in paraffin was used. After dewaxing, the sections were stained with hematoxylin and eosin.

The endometrial expression of VDR, CD4+Tcells, and CD8+Tcells was evaluated in 68 women of the sample: 18 - with pregnancy, 50 - with negative outcomes in ART programs. In this sample, 25 IVF programs and 43 IVF/ICSI programs were carried out.

For the immunohistochemical study of endometrial biopsies, the avidin-biotin immunoperoxidase method was used, with standard sets of polyclonal rabbit antibodies against VDR, CD4+T cells, CD8+T cells. The Histophine detection system was used to visualize the primary antibodies.

VDR expression was assessed by counting and percentage of stained stromal cells and endometrial glandulocytes. CD4+ and CD8+ endometrial stromal lymphocytes.

Morphofunctional assessment of the endometrium was performed using licensed software ("Morphology 5.2," Russia). The preparations were examined and photographed using a Primo Star microscope(Carl Zeiss, Germany), with the help of a Pixera Pro 150ES digital camera (Canon, Japan) at an operating magnification of $x 400$.

All patients were informed about the purpose and design of the work and gave their consent to participate in the study and publish its results in the open press. The study was approved by the SUSMU Ethics Committee.

Statistical analysis was performed using the IBM SPSS Statistics for Windows, Version 21.0. Armonk, NY: IBM Corp.). The normality of distribution of continuous variables was tested by the Kolmogorov-Smirnov test with the Lilliefors correction and Shapiro-Wilk test. Continuous variables with normal distribution were presented as mean (standard deviation [SD]); non-normal variables were reported as median (interquartile range [IQR])._Means of 2 continuous normally distributed variables were compared by independent samples Student's $t$ test._Differences of continuous variables departing from the normal distribution, even after transformation, were tested by the Mann-Whitney U-test. The frequencies of categorical variables were compared using Pearson's chi-squared test or Fisher's exact test, when appropriate. Spearman's rank correlation coefficient was calculated to measure the strength and direction of the relationship between two variables. Pearson's Correlation Coefficient ( $r$ ) was used to determine the strength of the relationship between the two continuous variables. A value of $P<0.05$ was considered significant.

\section{Results and Discussion}

The initial characteristics of infertile patients and the results of IVF and IVF-ICSI in the two groups are presented in Table 1 . There were no statistically significant differences in the serum content of $\mathrm{AMH}, \mathrm{FSH}$, the duration of the menstrual cycle, the results of IVF and IVF-ICSI protocols, as well as the thickness of the endometrium on the day of embryo transfer.

Table 1.

The results of IVF and IVF-ICSI in the two groups

\begin{tabular}{|l|c|c|c|}
\hline \multicolumn{1}{|c|}{ Parameter } & $\begin{array}{c}\text { Group 1 } \\
(\mathrm{n}=18)\end{array}$ & $\begin{array}{c}\text { Group 2 } \\
(\mathrm{n}=50)\end{array}$ & $P$-value \\
\hline Age of women. yrs & $38(37.5 ; 39.5)$ & $40(38 ; 41)$ & 0.139 \\
\hline $\begin{array}{l}\text { Duration of } \\
\text { the menstrual cycle }\end{array}$ & $28(28 ; 28.5)$ & $28(28 ; 29)$ & 0.771 \\
\hline AMH, ng/ml & $2.51(1.60 ; 3.68)$ & $1.4(0.74 ; 2.90)$ & 0.170 \\
\hline FSH, mME/ml & $7.45(5.72 ; 7.80)$ & $6.14(5.14 ; 8.70)$ & 0.337 \\
\hline Duration of stimulation & $10(10 ; 11)$ & $11(10 ; 11.25)$ & 0.108 \\
\hline Gonadotropin doses & $\begin{array}{c}2112.50 \\
(1500 ; 2250)\end{array}$ & $\begin{array}{c}2025 \\
(1650 ; 2475)\end{array}$ & 0.480 \\
\hline $\begin{array}{l}\text { The number of } \\
\text { follicles obtained }\end{array}$ & $8.5(4.75 ; 14.25)$ & $5.5(3 ; 10)$ & 0.690 \\
\hline $\begin{array}{l}\text { Number of } \\
\text { oocytes obtained }\end{array}$ & $6.5(4 ; 11.5)$ & $4.0(2 ; 8)$ & 0.058 \\
\hline $\begin{array}{l}\text { Number of } \\
\text { embryos obtained }\end{array}$ & $5.0(2 ; 9.25)$ & $3.0(1 ; 4)$ & 0.003 \\
\hline Transfer day & $5(4 ; 5)$ & $5(3 ; 5)$ & 0.558 \\
\hline $\begin{array}{l}\text { Number of } \\
\text { transferred embryos }\end{array}$ & $2(1.75 ; 2)$ & $1(1 ; 2)$ & 0.290 \\
\hline $\begin{array}{l}\text { Endometrial } \\
\text { thickness, mm }\end{array}$ & $10.35(9 ; 12)$ & $9.6(8.97 ; 12)$ & 0.316 \\
\hline
\end{tabular}


The number of obtained embryos in the group with favorable outcomes of IVF and IVF-ICSI protocols turned out to be almost one and a half times higher than with negative ones $(P=0.003)$.

Data on the vitamin D content in women's biological fluids, depending on the outcomes of the embryonic stage in IVF programs, are presented in Table 2. There were no differences in the content of $25(\mathrm{OH}) \mathrm{D}$ in the peripheral blood in the groups of infertile women; however, the mean vitamin D values in FF were higher, with the highest values in the group with the obtained embryos $(P=0.003)$. The level of vitamin $\mathrm{D}$ in biological fluids of women with different $\mathrm{AMH}$ did not show any statistically significant differences $(60.7 \pm 25.6$ and $80.3 \pm 24.0$, respectively).

\section{Table 2.}

Average content of $25(\mathrm{OH}) \mathrm{D}$ in blood serum and $\mathrm{FF}$, depending on the production of embryos

\begin{tabular}{|c|c|c|c|}
\hline Parameter & $\begin{array}{c}\text { Group with } \\
\text { obtained embryos } \\
(\mathrm{n}=115)\end{array}$ & $\begin{array}{c}\text { Group } \\
\text { without embryos } \\
(\mathrm{n}=32)\end{array}$ & $P$-value \\
\hline Blood serum, ng/ml & $55.1 \pm 14.1$ & $64.7 \pm 25.6$ & 0.364 \\
\hline Follicular fluid, ng/ml & $92.0 \pm 17.5$ & $78.3 \pm 27.0$ & 0.003 \\
\hline
\end{tabular}

Table 3.

Content of $25(\mathrm{OH}) \mathrm{D}(\mathrm{ng} / \mathrm{ml})$ in various biological fluids of women with different ART programs outcomes

\begin{tabular}{|c|c|c|c|}
\hline Parameter & $\begin{array}{l}\text { Group } 1 \\
(\mathrm{n}=37)\end{array}$ & $\begin{array}{l}\text { Group } 2 \\
(n=110)\end{array}$ & $P$-value \\
\hline \multicolumn{4}{|c|}{ in blood serum } \\
\hline$<20$ & - & $5(4.5 \%)$ & - \\
\hline $20-<30$ & $4(10.8 \%)$ & $52(42.3 \%)$ & 0.008 \\
\hline $30-<60$ & $33(89.2 \%)$ & $41(37.3 \%)$ & 0.009 \\
\hline$>$ more than 60 & - & $2(1.8 \%)$ & - \\
\hline \multicolumn{4}{|c|}{ in follicular fluid } \\
\hline$<20$ & - & $7(6.4 \%)$ & - \\
\hline $20-<30$ & - & $40(36.4 \%)$ & - \\
\hline $30-<60$ & $37(100 \%)$ & $68(61.8 \%)$ & 0.057 \\
\hline$>$ more than 60 & - & $2(1.8 \%)$ & - \\
\hline
\end{tabular}

Table 3 presents the frequency of different levels of the $25(\mathrm{OH}) \mathrm{D}$ in the blood serum and FF. Vitamin D deficiency $(<20 \mathrm{ng} / \mathrm{ml})$ in peripheral blood was detected only in Group 2. Excessive levels of vitamin D ( $>60 \mathrm{ng} / \mathrm{ml})$ were observed only in FF, but cases were rare. Low levels of vitamin D $(20-<30$ $\mathrm{ng} / \mathrm{ml}$ ) in women of this group were four times more frequent $(P=0.008)$ than in Group 1. Women with the onset of clinical pregnancy were more often distinguished by the optimal content of vitamin D in biological fluids - almost twice as much as those with ineffective attempts to treat infertility $(P=0.009$ for peripheral blood). The frequency of $25(\mathrm{OH}) \mathrm{D}$ concentrations from $30 \mathrm{ng} / \mathrm{ml}$ to $60 \mathrm{ng} / \mathrm{ml}$ in the FF of infertile women was higher than in the blood serum; for example it was $61.8 \%$ vs. $37.3 \%$, in Group 2. The average values of vitamin D in the blood serum and FF are presented in Table 4.

\section{Table 4.}

The average content of $25(\mathrm{OH}) \mathrm{D}$ in the blood serum and FF of women with different outcomes of IVF and IVF/ICSI programs

\begin{tabular}{|c|c|c|c|}
\hline \multicolumn{1}{|c|}{ Parameter } & $\begin{array}{c}\text { Group 1 } \\
(\mathrm{n}=37)\end{array}$ & $\begin{array}{c}\text { Group 2 } \\
(\mathrm{n}=110)\end{array}$ & $P$-value \\
\hline Blood serum, ng/ml & $48.9 \pm 10.4$ & $40.1 \pm 19.5$ & 0.550 \\
\hline Follicular fluid, ng/ml & $78.0 \pm 16.4$ & $61.8 \pm 23.7$ & 0.003 \\
\hline
\end{tabular}

The mean value of the $25(\mathrm{OH}) \mathrm{D}$ content in the blood serum in both groups did not differ; in FF it was significantly higher in Group 1 than in Group $2(P=0.003)$.

A strong correlation was revealed between the content of $25(\mathrm{OH}) \mathrm{D}$ in the blood serum and FF $(\mathrm{r}=0.67, P=0.003$ in both groups), a weak correlation - in cases where it was impossible to sample oocytes and/or embryos $(\mathrm{r}=0.48$, $P=0.06)$. Correlation of the $25(\mathrm{OH}) \mathrm{D}$ level in the blood serum and FF with the obtained follicles, oocytes and embryos was not detected. The optimal content of 25(OH)D in FF determined a greater probability of pregnancy.

Morphological examination of endometrial biopsies with H\&E staining showed the corresponding phase of the menstrual cycle: proliferation $(n=20)$, the middle stage of secretion $(n=68)$ during manipulation on Day 7 after confirmed ovulation. No lymphoid infiltration corresponding to the inflammatory process was detected in the samples.

In endometrial tissue samples, the VDR expression was observed in the nuclei of the stromal cells and glandulocytes of the glands. The VDR protein was also detected in the cytoplasm of endometrial gland cells.

Women of Group 1 were distinguished by a lower density of VDR distribution in the glands and stroma of the endometrium, in comparison to women of Group 2 (Figure 1, a, b; Figure 2 a, b).

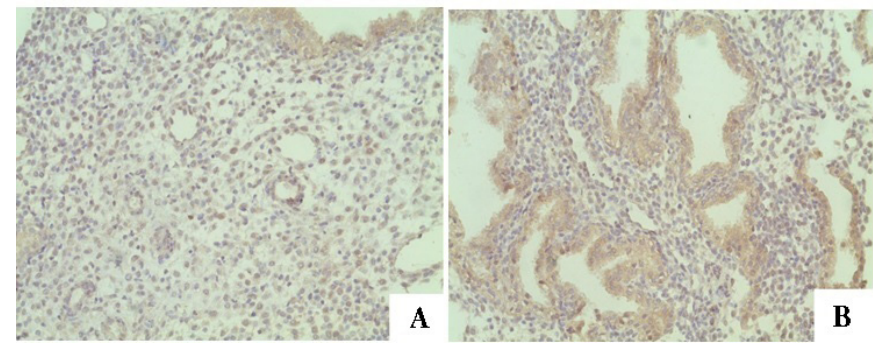

Fig. 1. VDR expression in the endometrium at the onset of implantation (clinical case). Immunohistochemical method: A $\times 200, B \times 200 ; A-V D R$ expression in glands $(3.6 \%) ; B-V D R$ expression in stroma $(7.0 \%)$

Timely delivery of a healthy fetus without complications. 


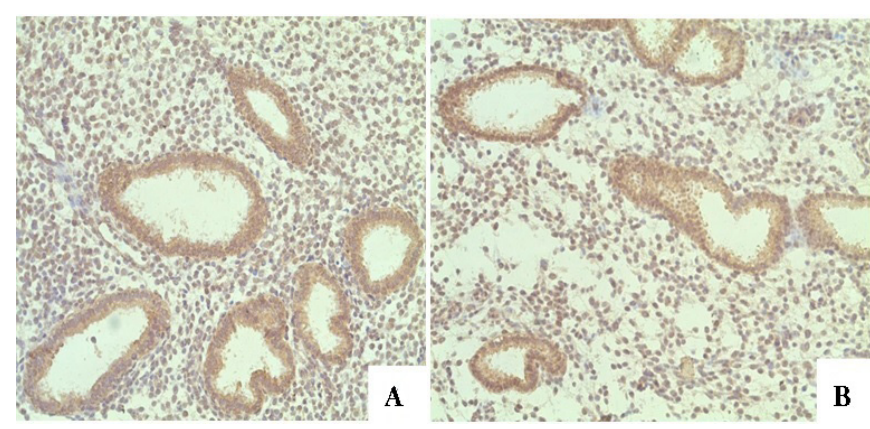

Fig. 2. VDR expression in the endometrium in the absence of implantation (clinical case). Immunohistochemical method: $A \times 200, B \times 200$. A - VDR expression in glands (6.9\%) $B-$ VDR expression in stroma $(10 \%)$

The VDR expression in the glands and stroma of the endometrium in the study groups is presented in Table 5. The VDR expression in stromal epithelium was higher in Group 2 than in Group $1(P=0,016)$.

Table 5.

VDR expression in the glands and stroma of the endometrium in women with different outcomes of IVF and IVF-ICSI protocols (\%)

\begin{tabular}{|c|c|c|c|}
\hline \multicolumn{1}{|c|}{ Parameter } & $\begin{array}{c}\text { Group 1 } \\
(\mathrm{n}=18)\end{array}$ & $\begin{array}{c}\text { Group 2 } \\
(\mathrm{n}=50)\end{array}$ & $P$-value \\
\hline VDR in the stroma & $7.0(4.3 ; 7.1)$ & $8.3(7.1 ; 8.7)$ & 0.016 \\
\hline VDR in the glands & $6.2(4.5 ; 8.6)$ & $8.8(7.4 ; 9.2)$ & 0.64 \\
\hline
\end{tabular}

There was a slight increase in the VDR expression in the cells of the stroma and glands in the luteal phase of the menstrual cycle; however, the differences were statistically insignificant, compared to the first phase (Table 6).

\section{Table 6.}

VDR expression in the glands and stroma of the endometrium in different phases of the menstrual cycle of infertile women (\%)

\begin{tabular}{|c|c|c|c|}
\hline \multicolumn{1}{|c|}{ Parameter } & $\begin{array}{c}\text { Phase I } \\
\text { of the cycle } \\
(\mathrm{n}=20)\end{array}$ & $\begin{array}{c}\text { Phase II } \\
\text { of the cycle } \\
(\mathrm{n}=20)\end{array}$ & $P$-value \\
\hline VDR in the stroma & $7.7(3.1 ; 9.1)$ & $8.64(6.5 ; 9.1)$ & 0.2 \\
\hline VDR in the glands & $7.8(2.9 ; 9.6)$ & $8.76(6.3 ; 10.2)$ & 0.33 \\
\hline
\end{tabular}

The area under the ROC-curve (AUC), calculated by the ROC-analysis method, allows verification of the prognostic coefficients of clinical pregnancy and the VDR expression in the cells of the stroma and glandulocytes of the endometrial glands. AUC of the VDR expression in the endometrial glands and stroma was $0.672 \pm 0.079$ (95\% CI: $0.52-0.83 ; P=0.03)$ and $0.74 \pm 0.06$ (95\% CI: 0.62-0.86; $P=0.003)$, respectively (Figure $3)$. The greatest prognostic potential was established for VDR expression in the endometrial stroma.

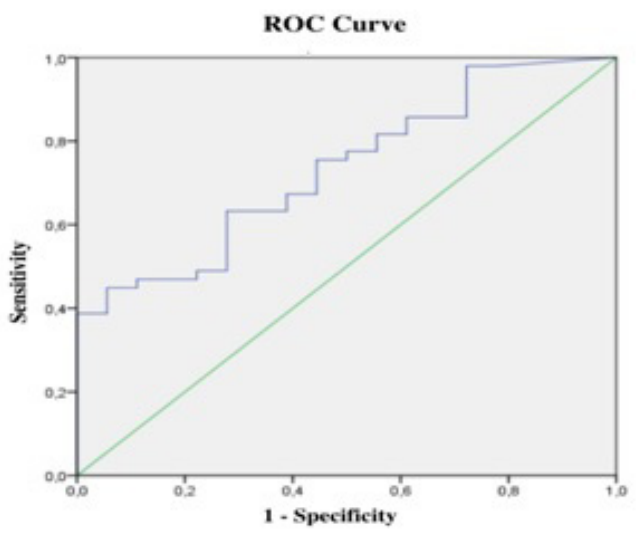

Fig. 3. ROC analysis of VDR expression in endometrial glands and stromal cells.

The threshold value of VDR expression in endometrial stroma cells at the cut-off point was $8.7 \%$. At the ROC threshold value of $<8.7 \%$, the endometrium was regarded as receptive, favorable for implantation; $\geq 8.7 \%$ - unfavorable. The sensitivity and specificity of the method were $100 \%$ and $40 \%$, respectively.

It is calculated that a $1 \%$ decrease in VDR expression in the stroma increases the chance of a favorable outcome by 1.35 times.

The expression of CD4+T cells and CD8+T cells (Figure $4, a, b)$ was identified by the brown staining of the membranes of the corresponding groups of antigen-positive endometrial stroma cells.

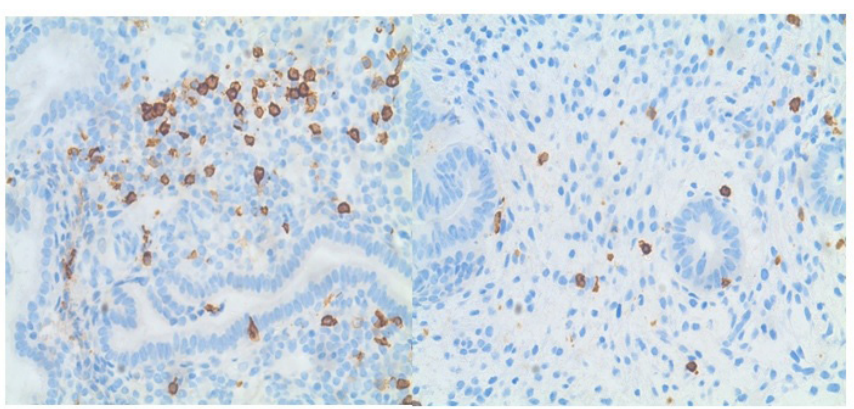

(a) (b)
Fig. 4. CD8+ expression in different outcomes of ART programs.

a. CD8+ expression in a negative ART outcome (2,203\%)

b. CD8+ expression in a positive ART outcome (0.68\%)

$a, b$-Immunohistochemical method, polymer test system $a, b-\times 400$

The expression of CD8+T cells was weaker in Group 1 than in Group 2 ( 0.77 and 1.07 , respectively). The expression level of labels of CD4+T cells in the groups did not visually differ. The density of labels of CD4+T cells and CD8+T cells in the endometrial stroma did not differ significantly between groups (Table 7).

The expression of CD4+T cells and CD8+T cells in endometrial samples taken from the same infertile women in different phases of the menstrual cycle showed no statistically significant differences (Table 8). 
The results of the analysis of correlations between the studied parameters are presented in Table 9. A moderate correlation was found between the expression of $\mathrm{CD} 4+\mathrm{T}$ cells and $\mathrm{CD} 8+\mathrm{T}$ cells in the endometrial stroma $(\mathrm{r}=0.361, P=0.004)$, as well as VDR in the stroma $(\mathrm{r}=0.310, P=0.013)$. There was no statistically significant correlation between the expression of $\mathrm{CD} 4+\mathrm{T}$ cells and VDR in glands $(\mathrm{r}=0.223, P=0.079)$. No correlation was also detected between the expression of CD8+T cells and VDR in the endometrial stroma $(\mathrm{r}=0.188$, $P=0.14)$, glands $(\mathrm{r}=0.040, P=0.754)$.

\section{Table 7.}

Expression of endometrial markers depending on the results of $A R T, \%$

\begin{tabular}{|l|c|c|c|}
\hline \multicolumn{1}{|c|}{ Marker } & $\begin{array}{c}\text { Group 1 } \\
(\mathrm{n}=18)\end{array}$ & $\begin{array}{c}\text { Group } 2 \\
(\mathrm{n}=50)\end{array}$ & $P$-value \\
\hline $\mathrm{CD} 4+$ & $0.96(0.80 ; 1.2)$ & $1.02(0.92 ; 1.17)$ & 0.12 \\
\hline $\mathrm{CD} 8+$ & $0.77(0.71 ; 1.18)$ & $1.07(1.01 ; 1.41)$ & 0.48 \\
\hline $\mathrm{CD} 4 / \mathrm{CD} 8$ & $1.24(0.94 ; 1.48)$ & $0.95(0.82 ; 1.21)$ & 0.08 \\
\hline
\end{tabular}

Table 8.

Expression of markers in different phases of the menstrual cycle, \%

\begin{tabular}{|l|c|c|c|}
\hline \multicolumn{1}{|c|}{ Marker } & $\begin{array}{c}\text { Phase I of the cycle } \\
(\mathrm{n}=20)\end{array}$ & $\begin{array}{c}\text { Phase II of the cycle } \\
(\mathrm{n}=20)\end{array}$ & $P$-value \\
\hline $\mathrm{CD} 4+$ & $0.99(0.68 ; 1.39)$ & $1.02(0.94 ; 1.16)$ & 0.705 \\
\hline $\mathrm{CD} 8+$ & $0.92(0.77 ; 1.36)$ & $1.06(0.68 ; 1.52)$ & 0.588 \\
\hline
\end{tabular}

Table 9.

Correlations between endometrial markers

\begin{tabular}{|c|c|c|c|c|}
\hline Marker & $\begin{array}{c}\text { VDR } \\
\text { in the stroma }\end{array}$ & $\begin{array}{c}\text { VDR } \\
\text { in the glands }\end{array}$ & CD4+ & $\mathrm{CD} 8+$ \\
\hline $\begin{array}{c}\text { VDR in } \\
\text { the stroma }\end{array}$ & - & $\begin{array}{l}\mathrm{r}=0.656, \\
P=0.000\end{array}$ & $\begin{array}{c}\mathrm{r}=0.310, \\
P=0.013\end{array}$ & $\begin{array}{c}\mathrm{r}=0.188, \\
P=0.14\end{array}$ \\
\hline $\begin{array}{c}\text { VDR in } \\
\text { the glands }\end{array}$ & $\begin{array}{c}\mathrm{r}=0.656, \\
P=0.000\end{array}$ & - & $\begin{array}{l}\mathrm{r}=0.223, \\
P=0.079\end{array}$ & $\begin{array}{c}\mathrm{r}=0.040, \\
P=0.754\end{array}$ \\
\hline CD4+ & $\begin{array}{c}\mathrm{r}=0.310, \\
P=0.013\end{array}$ & $\begin{array}{l}\mathrm{r}=0.223, \\
P=0.079\end{array}$ & - & $\begin{array}{l}\mathrm{r}=0.361, \\
P=0.004\end{array}$ \\
\hline CD8+ & $\begin{array}{c}\mathrm{r}=0.188, \\
P=0.14\end{array}$ & $\begin{array}{c}\mathrm{r}=0.040, \\
P=0.754\end{array}$ & $\begin{array}{l}\mathrm{r}=0.361, \\
P=0.004\end{array}$ & - \\
\hline
\end{tabular}

\section{Discussion}

Ineffective IVF attempts on the background of low serum vitamin D levels correspond to the reports of a reduced chance of childbearing in contrast to clinical pregnancy in a meta-analysis of 9 studies (3693 cycles). ${ }^{(30)}$

There is a high probability of implantation and clinical pregnancy in ART protocols with a sufficient (30$<60 \mathrm{ng} / \mathrm{ml}$ ) content of vitamin $\mathrm{D}$ in the blood serum and FF in comparison to its deficiency $(P<0.05)$. The average level of vitamin $\mathrm{D}$ in the $\mathrm{FF}$ of all infertile women was higher than in the blood serum. Women who received embryos in the ART protocols had higher $25(\mathrm{OH}) \mathrm{D}$ values in $\mathrm{FF}$ $(P=0.003)$. A higher concentration of vitamin $\mathrm{D}$ in $\mathrm{FF}$ was found in women with clinical pregnancy $(P=0.003)$. The data obtained are consistent with the results of Ozkan et al., ${ }^{(31)}$ who indicated an increase in the probability of clinical pregnancy by $6 \%$ with an increase in $25(\mathrm{OH}) \mathrm{D}$ per $1 \mathrm{ng} / \mathrm{ml}$ in $\mathrm{FF}(P=0.03)$.

Our results show that the level of vitamin $25(\mathrm{OH}) \mathrm{D}$ in $\mathrm{FF}$ is a significant factor for the outcomes of IVF and IVF/ ICSI protocols. The effect of vitamin D on implantation and clinical pregnancy in IVF protocols should be considered from the standpoint of various biological functions: inhibition of cell proliferation, angiogenesis, and antioxidant activity. The revealed correlation between the content of vitamin $\mathrm{D}$ in blood serum and FF is consistent with the results obtained by Firouzabadi et al. ${ }^{(32)} \mathrm{We}$ believe that the lack and deficiency of vitamin D plays a significant role in predicting unfavorable outcomes of ART programs, in contrast to the conclusions of A. Aleyasin et al., ${ }^{(16)}$ who did not reveal differences in the content of vitamin $\mathrm{D}$ in the $\mathrm{FF}$ in women with and without pregnancy in the protocols.

A higher concentration of $25(\mathrm{OH}) \mathrm{D}$ in the blood serum is likely to modulate the immunosuppressive effect in the endometrium, which is favorable for the nidation of the blastocyst. Evans et al. ${ }^{(33)}$ link similar biological functions to local vitamin metabolites and the production of $1,25(\mathrm{OH}) 2 \mathrm{D} 3$ in the mucosa in early pregnancy. The metabolic effects of vitamin $\mathrm{D}$ in the endometrium should be considered from the perspective of VDR distribution. The expression of the protein in the cytoplasm of the endometrial glands corresponds to the data on the interaction of the active form 1,25(OH)2D with the nuclear receptor and further transport to the nucleus with the realization of the effects of the vitamin D-VDR complex. ${ }^{(34-36)}$ The revealed decrease in VDR expression in the endometrium during the "implantation window," especially in stromal cells, allows us to speculate about the progesterone-like activity of vitamin $\mathrm{D}$, alongside the restriction of local proinflammatory reactions necessary for blastocyst implantation.

We believe that the combination of optimal serum vitamin D levels and low VDR expression in the stroma has a beneficial effect on implantation and outcomes of IVF and IVF/ICSI programs. Similar data were presented by Zelenko et al., ${ }^{(37)}$ when studying the endometrium of women with endometriosis as opposed to healthy ones. The results of the study performed by Guo et al. ${ }^{(38)}$ were opposite. The authors reported higher VDR expression in the endometrium of women (average age 34.6 years) with the onset of pregnancy. In our study, there were no differences in the VDR expression 
in the proliferative and secretory phases of the menstrual cycle, which was consistent with the results of Vienonen et al., ${ }^{(39)}$ who studied the endometrium of premenopausal women.

The positive effect of a lower expression of $\mathrm{CD} 8+\mathrm{T}$ cells in the endometrium of women before embryo transfer on the outcomes of IVF and IVF/ICSI programs corresponds to the study by Lachapelle et al. ${ }^{(40)}$ in women with recurrent miscarriage. Conclusions about the probability of reproductive losses or implantation failures are logical in cases of high expression of lymphocyte subpopulations in the endometrium, including NK, B-cells, CD4+T cells, and CD8+T cells. ${ }^{(41)}$

The data obtained suggest that the endometrial susceptibility during implantation is influenced not only by the moderate activity of the D-VDR complex, determined by factors involved in the metabolic transformations of vitamin $\mathrm{D}$, but also by the ratio of immune cell subpopulations. The role of reducing the expression of cytotoxic CD8+T cells is most significant for the invasion of blastocysts containing semi-allogeneic fetal cells. The data obtained make it possible to assume that the prognosis of favorable outcomes of ART programs is based on the activity of signaling molecules in the endometrium, which act as "subtle" mechanisms of fertility regulation.

\section{Conclusion}

We determined a great prognostic significance for VDR expression in the endometrial stroma. The absence of differences in VDR expression in the stroma and endometrial glands, as well as CD4+T cells and CD8+T cells in different phases of the menstrual cycle of infertile women characterizes an impaired endometrial functional activity. Favorable outcomes of ART programs are determined by a decrease in the VDR expression in the endometrial stroma: with a reduction by $1 \%$, the chances increase by 1.3 times. A decrease in the level of the endometrial CD8+T cells is significant for ensuring immunological tolerance in the mother-embryo system and predicting favorable outcomes of ART programs. Morphofunctional peculiarities of the endometrium of infertile women are the basis for predicting the outcomes of ART programs and preparing for pregnancy.

\section{Acknowledgments}

This research was funded by RFBR and Chelyabinsk Region, Project number 20-415-740014.

\section{Competing Interests}

The authors declare that they have no competing interests.

\section{References}

1. Herington JL, Guo Y, Reese J, Paria BC. Gene profiling the window of implantation: Microarray analyses from human and rodent models. J Reprod Health Med. 2016 Dec;2(Suppl 2):S19-S25. doi: 10.1016/j.jrhm.2016.11.006.

2. van Mourik MS, Macklon NS, Heijnen CJ. Embryonic implantation: cytokines, adhesion molecules, and immune cells in establishing an implantation environment. J Leukoc Biol. 2009 Jan;85(1):4-19. doi: 10.1189/jlb.0708395.

3. Moffett A, Colucci F. Uterine NK cells: active regulators at the maternal-fetal interface. J Clin Invest. 2014 May;124(5):1872-9. doi: 10.1172/JCI68107.

4. Moffett A, Shreeve N. Reply: First do no harm: continuing the uterine NK cell debate. Hum Reprod. 2016 Jan;31(1):218-9. doi: 10.1093/humrep/dev290.

5. Gellersen B, Brosens JJ. Cyclic decidualization of the human endometrium in reproductive health and failure. Endocr Rev. 2014 Dec;35(6):851-905. doi: 10.1210/er.20141045.

6. Adams JS, Hewison M. Unexpected actions of vitamin D: new perspectives on the regulation of innate and adaptive immunity. Nat Clin Pract Endocrinol Metab. 2008 Feb;4(2):80-90. doi: 10.1038/ncpendmet0716.

7. Duda-Wiewiórka M, Pityński K. [Vitamin D in normal and pathologically changed endometrium]. Wiad Lek. 2019;72(3):452-456. [Article in Polish].

8. Lerchbaum E, Obermayer-Pietsch B. Vitamin D and fertility: a systematic review. Eur J Endocrinol. 2012 May;166(5):765-78. doi: 10.1530/EJE-11-0984.

9. Anagnostis P, Karras S, Goulis DG. Vitamin D in human reproduction: a narrative review. Int J Clin Pract. 2013 Mar;67(3):225-35. doi: 10.1111/ijcp.12031.

10. Cermisoni GC, Alteri A, Corti L, Rabellotti E, Papaleo E, Viganò P, Sanchez AM. Vitamin D and Endometrium: A Systematic Review of a Neglected Area of Research. Int J Mol Sci. 2018 Aug 8;19(8):2320. doi: 10.3390/ijms19082320.

11. Hii CS, Ferrante A. The Non-Genomic Actions of Vitamin D. Nutrients. 2016 Mar 2;8(3):135. doi: 10.3390/ nu8030135.

12. Viganò $\mathrm{P}$, Lattuada $\mathrm{D}$, Mangioni $\mathrm{S}$, Ermellino L, Vignali M, Caporizzo E, Panina-Bordignon P, Besozzi M, Di Blasio AM. Cycling and early pregnant endometrium as a site of regulated expression of the vitamin D system. J Mol Endocrinol. 2006 Jun;36(3):415-24. doi: 10.1677/ jme.1.01946.

13. Grzesiak M, Waszkiewicz E, Wojtas M, Kowalik $\mathrm{K}$, Franczak A. Expression of vitamin D receptor in the porcine uterus and effect of $1,25(\mathrm{OH})_{2} \mathrm{D}_{3}$ on progesterone and estradiol-17 $\beta$ secretion by uterine tissues in vitro. Theriogenology. 2019 Feb;125:102-108. doi: 10.1016/j. theriogenology.2018.10.026.

14. Saccone D, Asani F, Bornman L. Regulation of the vitamin $\mathrm{D}$ receptor gene by environment, genetics and epigenetics. Gene. 2015 May 1;561(2):171-80. doi: 10.1016/j.gene.2015.02.024.

15. Pacis MM, Fortin CN, Zarek SM, Mumford SL, Segars $\mathrm{JH}$. Vitamin D and assisted reproduction: should vitamin D be routinely screened and repleted prior to ART? A systematic review. J Assist Reprod Genet. 2015 Mar;32(3):323-35. doi: 10.1007/s10815-014-0407-9.

16. Aleyasin A, Hosseini MA, Mahdavi A, Safdarian L, Fallahi P, Mohajeri MR, Abbasi M, Esfahani F. Predictive 
value of the level of vitamin $\mathrm{D}$ in follicular fluid on the outcome of assisted reproductive technology. Eur J Obstet Gynecol Reprod Biol. 2011 Nov;159(1):132-7. doi: 10.1016/j.ejogrb.2011.07.006.

17. Rajaei S, Mirahmadian M, Jeddi-Tehrani M, Tavakoli M, Zonoobi M, Dabbagh A, Zarnani AH. Effect of $1,25(\mathrm{OH}) 2$ vitamin D3 on cytokine production by endometrial cells of women with repeated implantation failure. Gynecol Endocrinol. 2012 Nov;28(11):906-11. doi: 10.3109/09513590.2012.683062.

18. Wojtusik J, Johnson PA. Vitamin D regulates antiMullerian hormone expression in granulosa cells of the hen. Biol Reprod. 2012 Mar 30;86(3):91. doi: 10.1095/ biolreprod.111.094110.

19. Polyzos NP, Anckaert E, Guzman L, Schiettecatte J, Van Landuyt L, Camus M, Smitz J, Tournaye H. Vitamin D deficiency and pregnancy rates in women undergoing single embryo, blastocyst stage, transfer (SET) for IVF/ICSI. Hum Reprod. 2014 Sep;29(9):2032-40. doi: 10.1093/humrep/ deu156.

20. Rudick B, Ingles S, Chung K, Stanczyk F, Paulson R, Bendikson K. Characterizing the influence of vitamin D levels on IVF outcomes. Hum Reprod. 2012 Nov;27(11):3321-7. doi: 10.1093/humrep/des280.

21. Rudick BJ, Ingles SA, Chung K, Stanczyk FZ, Paulson RJ, Bendikson KA. Influence of vitamin D levels on in vitro fertilization outcomes in donor-recipient cycles. Fertil Steril. 2014 Feb;101(2):447-52. doi: 10.1016/j. fertnstert.2013.10.008.

22. Lv SS, Wang JY, Wang XQ, Wang Y, Xu Y. Serum vitamin $\mathrm{D}$ status and in vitro fertilization outcomes: a systematic review and meta-analysis. Arch Gynecol Obstet. 2016 Jun;293(6):1339-45. doi: 10.1007/s00404-016-4058-1. 23. Neville G, Martyn F, Kilbane M, O'Riordan M, Wingfield M, McKenna M, McAuliffe FM. Vitamin D status and fertility outcomes during winter among couples undergoing in vitro fertilization/intracytoplasmic sperm injection. Int $\mathrm{J}$ Gynaecol Obstet. 2016 Nov;135(2):172-176. doi: 10.1016/j. ijgo.2016.04.018.

24. Franasiak JM, Molinaro TA, Dubell EK, Scott KL, Ruiz AR, Forman EJ, Werner MD, Hong KH, Scott RT Jr. Vitamin D levels do not affect IVF outcomes following the transfer of euploid blastocysts. Am J Obstet Gynecol. 2015 Mar;212(3):315.e1-6. doi: 10.1016/j.ajog.2014.09.029.

25. van de Vijver A, Drakopoulos P, Van Landuyt L, Vaiarelli A, Blockeel C, Santos-Ribeiro S, Tournaye H, Polyzos NP. Vitamin D deficiency and pregnancy rates following frozenthawed embryo transfer: a prospective cohort study. Hum Reprod. 2016 Aug;31(8):1749-54. doi: 10.1093/humrep/ dew107.

26. Cappy H, Giacobini P, Pigny P, Bruyneel A, LeroyBilliard M, Dewailly D, Catteau-Jonard S. Low vitamin D3 and high anti-Müllerian hormone serum levels in the polycystic ovary syndrome (PCOS): Is there a link? Ann

*Corresponding author: Elena G. Chukhnina, PGS. Department of Pathological Anatomy and Forensic Medicine, South Ural State Medical University, Chelyabinsk, Russia. E-mail: chuhninaeg@yandex.ru
Endocrinol (Paris). 2016 Oct;77(5):593-599. doi: 10.1016/j. ando.2016.02.001.

27. Saito S, Nakashima A, Shima T, Ito M. Th1/Th2/Th17 and regulatory T-cell paradigm in pregnancy. Am J Reprod Immunol. 2010 Jun;63(6):601-10. doi: 10.1111/j.16000897.2010.00852.x.

28. Piccinni MP, Scaletti C, Maggi E, Romagnani S. Role of hormone-controlled Th1- and Th2-type cytokines in successful pregnancy. J Neuroimmunol. 2000 Sep 1;109(1):30-3. doi: 10.1016/s0165-5728(00)00299-x.

29. Paramonova NB, Kogan EA, Kolotovkina AV, Burmenskaya OV. Morfologicheskie i molekuliarnobiologicheskie priznaki narusheniia retseptivnosti éndometriia pri besplodii zhenshchin, stradaiushchikh naruzhnym genital'nym éndometriozom [The morphological and molecular biological signs of impaired endometrial receptivity in infertility in women suffering from external genital endometriosis]. Arkh Patol. 2018;80(3):11-18. doi: 10.17116/patol201880311-18. [Article in Russian].

30. Zhao J, Huang X, Xu B, Yan Y, Zhang Q, Li Y. Whether vitamin $\mathrm{D}$ was associated with clinical outcome after IVF/ ICSI: a systematic review and meta-analysis. Reprod Biol Endocrinol. 2018 Feb 9;16(1):13. doi: 10.1186/s12958-0180324-3.

31. Ozkan S, Jindal S, Greenseid K, Shu J, Zeitlian G, Hickmon C, Pal L. Replete vitamin D stores predict reproductive success following in vitro fertilization. Fertil Steril. 2010 Sep;94(4):1314-1319. doi: 10.1016/j. fertnstert.2009.05.019.

32. Firouzabadi RD, Rahmani E, Rahsepar M, Firouzabadi MM. Value of follicular fluid vitamin $D$ in predicting the pregnancy rate in an IVF program. Arch Gynecol Obstet. 2014 Jan;289(1):201-6. doi: 10.1007/s00404-013-2959-9.

33. Evans KN, Nguyen L, Chan J, Innes BA, Bulmer JN, Kilby MD, Hewison M. Effects of 25-hydroxyvitamin D3 and 1,25-dihydroxyvitamin D3 on cytokine production by human decidual cells. Biol Reprod. 2006 Dec;75(6):816-22. doi: 10.1095/biolreprod.106.054056.

34. Sayem ASM, Giribabu N, Karim K, Si LK, Muniandy $\mathrm{S}$, Salleh N. Differential expression of the receptors for thyroid hormone, thyroid stimulating hormone, vitamin D and retinoic acid and extracellular signal-regulated kinase in uterus of rats under influence of sex-steroids. Biomed Pharmacother. 2018 Apr;100:132-141. doi: 10.1016/j. biopha.2018.02.008.

35. Emam MA, Abouelroos ME, Gad FA. Expression of calbindin-D9k and vitamin $\mathrm{D}$ receptor in the uterus of Egyptian buffalo during follicular and luteal phases. Acta Histochem. 2016 Jun;118(5):471-7. doi: 10.1016/j. acthis.2016.04.009.

36. Jang H, Choi Y, Yoo I, Han J, Hong JS, Kim YY, Ka H. Vitamin D-metabolic enzymes and related molecules: Expression at the maternal-conceptus interface and the role of vitamin $\mathrm{D}$ in endometrial gene expression in pigs. PLoS One. 2017 Oct 31;12(10):e0187221. doi: 10.1371/journal. pone.0187221.

37. Zelenko Z, Aghajanova L, Irwin JC, Giudice LC. Nuclear receptor, coregulator signaling, and chromatin remodeling pathways suggest involvement of the epigenome in the steroid hormone response of endometrium and abnormalities 
in endometriosis. Reprod Sci. 2012 Feb;19(2):152-62. doi: 10.1177/1933719111415546.

38. Guo J, Liu S, Wang P, Ren H, Li Y. Characterization of VDR and CYP27B1 expression in the endometrium during the menstrual cycle before embryo transfer: implications for endometrial receptivity. Reprod Biol Endocrinol. 2020 Mar 17;18(1):24. doi: 10.1186/s12958-020-00579-y.

39. Vienonen A, Miettinen S, Bläuer M, Martikainen PM, Tomás E, Heinonen PK, Ylikomi T. Expression of nuclear receptors and cofactors in human endometrium and myometrium. J Soc Gynecol Investig. 2004 Feb;11(2):10412. doi: 10.1016/j.jsgi.2003.09.003.

40. Lachapelle MH, Miron P, Hemmings R, Roy DC. Endometrial T, B, and NK cells in patients with recurrent spontaneous abortion. Altered profile and pregnancy outcome. J Immunol. 1996 May 15;156(10):4027-34.

41. Marron K, Harrity C. Endometrial lymphocyte concentrations in adverse reproductive outcome populations. J Assist Reprod Genet. 2019 May;36(5):837-846. doi: 10.1007/s10815-019-01427-8. 